IBT Journal of Business Studies (IBT-JBS)

E-ISSN: 2409-6520; P-ISSN: 2414-8393

Volume 16:, 141-150 (2020)

DOI: $10.46745 /$ ILMA.jbs.2020.161.01

\title{
Workable Performance Management System for Government of Pakistan
}

\section{Received: 20-Apr-2020 | Accepted: 13-Jul-2020}

\author{
Kaifee Siddiqui ${ }^{*}$ iD
}

\begin{abstract}
There is a lot of debate in Pakistan on and about the poor performance of the government and the bureaucracy. The performance of the government is marred by the corrupt practices, inefficiencies and waste. The political leadership and bureaucracy both are publically called corrupt and stories appear on news, media channels every now and then of the corruption scandals, misuse of authority and wasteful working. We rank the lowest amongst the nations in terms of basic government services like education and healthcare. This paper aims to highlight the reasons of this poor performance and recommends a workable performance management program which can help the government in improving the performance of its various functions. It also gives an over view of the current practices of performance management system in the public sector of Pakistan and discusses briefly the history of performance management in the modern world. Most importantly we discuss the challenges we face while implementing a performance management system in government sector, what are the differences between a private sector performance management program and the problems we face when we implement it in public sector in a developing world specially in a country like Pakistan. The challenges become even more profound when we face a democracy where the political interference has destroyed the core of the bureaucratic structure. But all is not lost since many reforms over the past few decades put in place by successive governments have at-least paved the way for a more progressive performance management program which can help Pakistan deliver on its promise of becoming a great Islamic republic. The Islamic republic of Pakistan.
\end{abstract}

Keywords: Performance management, Public Sector, Bureaucracy

JEL Classification: $H 11, E 42, G 18, G 28, G 38$

\section{Author's Affiliation: \\ Institution: \\ Karachi University ${ }^{1}$ \\ Country: \\ Pakistan \\ Corresponding Author’s Email: $\quad *$ Siddiqui.kaifee@gmail.com}

The material presented by the author(s) does not necessarily portray the view point of the editors and the management of the ILMA University, Pakistan.

2409-6520 (Online) 2414-8393 (Print) (C2020, published by the ILMA University, Pakistan.

This is open access article under the @ $\odot$ license. https://creativecommons.org/licenses/by/4.0/

Page | 141 


\section{1) INTRODUCTION}

Since the time of its birth, Pakistan has been struggling with the issues of resources and human capital. Over the years, resources increased but no effort was made to institutionalize human capital of the country. The bureaucratic structure which was inherited from the British was adopted without any material changes. This structure had its roots in the colonial philosophy with a strong emphasis on power for the rulers with very little accountability. However, in the past couple of decades we have witnessed some effort (though half hearted) to reform this structure. Most noteworthy is the use of performance management system being one of the reforms which will have a far-reaching impact on the efficiency and effectiveness of the bureaucratic structure of the country.

Unfortunately, we can clearly see that performance management has not worked well in Pakistan. This is mainly due to the fact that performance measures are often not used in program reviews or budget processes based on political realities. Also, the periodic changes or reforms that have been made are primarily procedural and cosmetic with little or no impact on the effectiveness of the program.

\section{2) LITERATURE REVIEW}

While we can trace the records of evaluating students in the early universities as well as evaluating soldiers for physical and mental strength hundreds of years ago. Bureaucracies have been evaluating employee performance for thousands of years. Chinese civil servants and military officers underwent mental, moral, and physical fitness evaluations as far back as 200 BCE (Danielle, Wiese and Ronald (1998). In the Middle Ages, European Guilds used evaluations for certifying craftsmen as Masters, and early universities used exams to evaluate students of divinity and the liberal arts.

However, a scientifically backed performance management solution is only about 100 years old. Taylor summed up his work in his book The Principles of Scientific Management which was voted the most influential management book of the twentieth century. Taylor (1911) proposed an efficiency model that became the basis of the modern performance management system and showed the world that how a properly designed scientific performance management program can improve productivity. Frederick Taylor's scientific management theory, also called the classical management theory, proved to be one of the most influential works in the performance management systems around the world. The writer himself says the larger profit would come to the whole world in general (Taylor, 1911).

Before we discuss the performance management in public sector or in bureaucratic structures we need to understand the theory of bureaucracy as propounded by Max Weber. Max Weber is thought to be the master mind of the theory of bureaucracy who declared that there must be a set of rules to guide the authorities in carrying out the official duties. He also opined that there must be a set of pre-qualifications and pre-requisites to join the bureaucracy along with the structure of hierarchy. He 
made it mandatory for officials to be impartial in discharging their duties without any loyalty to the ruler. He though that the officers must be appointed for life with the relevant pension and retirement benefits and must undergo periodic trainings to keep them abreast of how the work is done in public offices (Waters \& Waters, 2015).

This theory by Max Weber is still valid for the Civil Service of Pakistan and we can see and taste its flavour in the operation and structure of the government sector in Pakistan. However, since we inherited the colonial structure which was primarily designed to keep the subjects subjugated, therefore the check and balance of the structure proposed by Max Weber never came into practice in Pakistan. Which allowed the political leadership to capitalize on and exploit this weakness of the system to the detriment of the people of Pakistan.

\section{PUBLIC SECTOR PERFORMANCE MANAGEMENT IN PAKISTAN}

Performance management is a systematic approach to improve performance. But it is easier said than done. It has not even worked for many Large private sector organizations so how can we expect to work for huge public administration set up. Thomas Woodrow Wilson (1856 - 1924) was an American politician and academic who served as the 28th President Of USA. from 1913 to 1921 . He is considered the father of public administration in the United States. He first formally recognized public administration in an 1887 article entitled The Study of Administration. He wrote that "it is the object of administrative study to discover, first, what government can properly and successfully do, and, secondly, how it can do these proper things with the utmost possible efficiency and at the least possible cost either of money or of energy (Wilson, 1887).

So how can the efficiency be brought about in Public administration. The answer is a scientific method which is Performance management to improve performance. It requires many wheels to turn simultaneously just like the wheels of a car.

First wheel is the performance measurement. It is important to measure the input and output of a particular process or a system. In private sector the performance measurement is focused on things like profitability, market share, costs etc. However, it may not be relevant for most of the Public sector organizations. Hence the stepsister's Predicament ("if The Shoe Doesn't Fit, Get Another" We need a new set of performance measurements for public sector organization like outcome of the intended policy, efficiency and effectiveness of the program and most importantly transparency.

Second wheel is the performance evaluation which comes with an integrated set of consequences. In private sector, it is done through a rating scale or ranking system which then translates into salary increases and bonuses in accordance with the evaluation. In public sector this may mean a whole new world, requiring the entire system to be put upside down. Here we must remember The Titanic Warning "It's What You Can't See That Can Sink You" As Daley writes in article, Judgmental 
techniques (which are more prevalent) follow the old command and control model of authority. They are quite explicitly linked to extrinsic rewards. In fact, the existence and adequacy of the reward structure is an important subsidiary question with regard to their effectiveness. This has proved an important limitation in their use among public sector agencies (Dennis, 1991).

In Public sector organizations we need new set of rules for interpreting performance measurement information, criteria and the consequence to go with it, just like we needed new set of performance measurement. First challenge comes with the interpretation of performance measurement information to justify money spent by the government. This requires a three-dimensional approach, the outcome of the intended policy, efficiency \& effectiveness of the program and the transparency. 2nd challenge is the consequence which is constrained by the laws of the government, political interference and historically embedded corrupt practices in our bureaucratic hierarchy down to the core from top down to bottom up. Remember the Heisenberg Dilemma "Beware of the Law of Unintended Consequences"

On the face of it it looks difficult to overcome this three-dimensional challenge of evaluation and it certainly looks impossible to break free from the threedimensional chain of consequences. In other words, are we saying that we, the citizens of Pakistan will never see the light of the day? We will never be able to see the promised results of the performance management movement which has proved so helpful in many of the developed countries? No. Not at all we aren't saying it cannot be implemented in Pakistan. This aspect will be discussed in detail in the recommendation section.

Third wheel is the capacity building of the incumbents to continuously and consistently improve the performance so that the bar continues to go higher and higher and standards continue to improve. Private sector manages it through training in the current role \& development for the future roles. In Public sector training is treated as a reward and used for select few. Which in turn destroys the spirit of development and the need to put in practice the newly learned skills by the individuals. More importantly training must be used to improve the performance standards. As Daley notes that performance standards are meant to anchor an appraisal system to specific, job-related tasks. Inasmuch as they are consistent with written position descriptions (the basis/contract requirements upon which people are hired), they reinforce this connection between job and assessment of an employee's performance in the job. In addition, they help to communicate to the employee a clear understanding of job expectations (Dennis, 1991).

Fourth wheel is the process of implementation of the performance management program which requires lot of effort, commitment from the political leadership, bureaucratic leadership and the citizens. It also requires scientific techniques of change management principles to implement such a major change. Absence of this wheel has practically nullified every effort of the establishment division to promote performance management program in Pakistan. This wheel requires more detailed analysis and discussion which is done in this paper under performance prism and strategies and process implementation sections. 


\section{3) RESEARCH METHODOLOGY}

The method used primarily to evaluate performance in Federal and Provincial Civil Service, is Performance Evaluation Report (PER), formerly called as Annual Confidential Report (ACR). Senior officer of the incumbent civil servant fills this report and it is done annually.

Public Sector in Pakistan is mandated by Establishment division to implement performance management system by the PAKISTAN PUBLICADMINISTRATION, RESEARCH CENTRE, MANAGEMENT SERVICES WING, ESTABLISHMENT DIVISION, ISLAMABAD (Edition 2004). This Edition and the previous directives of the establishment division directed and guided the federal government departments to implement performance management system. Process is also defined in the guidelines, i.e. how to fill out the forms and reports (A Guide to Performance Evaluation, 2004).

Goals were to be set at the beginning of the performance year, reports were to be submitted to measure progress against the goals. It also had directions, guidelines and various forms to fill out by the staff at various levels in the government hierarchy (A Guide to Performance Evaluation, 2004).

There are many types of performance evaluation forms for officers according to the civil servants' ranks. PERs are provided by Establishment division. For example, the PER form for officers in BPS-17 contains: (1) personal information of the officer, (2) self- evaluation of the officer by himself/herself, (3) evaluation of personal qualities by reporting officer, (4) pen picture, overall grading and fitness for promotion by reporting officer, (5) remarks of the countersigning officer and (6) remarks of the second countersigning officer. PER form for officers in BPS-19 and 20 is the same except the fitness for promotion part. PER form for officers in BPS21 has three parts: (1) personal information of the officer, (2) self -evaluation of the officer by himself/herself and (3) evaluation of personal qualities and pen picture by reporting officer (Hanif, Jabeen \& Jadoon, 2016).

\section{4) RESULTS}

A survey was conducted amongst the bureaucrats by Haque and Khawaja and the findings were in line with the general perception of populace of Pakistan. Following statement of the findings as reported in the report by Haque and Khawaja is alarming.

$93 \%$ in the given sample felt that performance has deteriorated over the years and $38 \%$ of them thought that the deterioration is extreme. (Haque, \& IKhawaja, 2007)

\section{5) RECOMMENDATION}

Before we start to implement any kind of reform and that too such a major change like a performance management system, we must recognize our political limitations. In Pakistan we would like the democracy to continue and in politics everything comes down to politics. This holds true for the entire democratic world whether Page | 145 
developed or developing world.

This means that all performance measures will be subjected to political will. The performance measures specifically evaluations and accountability will be and must viewed through the electorate lens. As long as we do not recognize this limitation and make it work to our advantage, all our efforts to implement performance management system will go down the drain.

According to the interviews conducted by Ayesha Hanif University of the Punjab, Lahore. Nasira Jabeen University of the Punjab, Lahore. Zafar Iqbal Jadoon University of Central Punjab, Lahore. political meddling and interference were highlighted as the most important factor affecting not only performance but also the entire functioning and working of civil service. One senior bureaucrat viewed that merit starts deteriorating when no matter how sluggish or dim witted the officer is, he/she gets good scoring on PER and also better transfer and places of posting on the basis of political connections. Lack of merit-based transfers and postings make officials unconditionally loyal to their political masters and this fear factor heavily influences performance of the civil servants (Hanif, Jabeen \& Jadoon, 2016).

All new literature on performance management programs are perfectly designed to match the private sector efforts to improve the productivity and efficiency starting from Frederick Tylor to this day. Although there is broad agreement that some form of performance measurement system is an important component of organisational control there is no general model that provides a precise prescription of such a system. (Fitzgerald, 2001) But nothing works for government sector. Even the latest versions of Kaplan's balance score card Which state that what you measure is what you get is not enough for public sector organizations and the government functions. (Kaplan \& Norton 1992) Lynch and Cross performance pyramid also does not fit the glove of public sector performance management requirements. However, one theory proposed by Andy Neely and Chris Adams is worth a closer look. They call their performance management frame work a Performance Prism. The most important element of this new frame work is that it not only recognizes the existence of Stakeholders which are currently not considered stakeholders for the performance management frame works but it also requires them and quantify their contribution. There is a 'quid pro quo' between the all its stakeholders stakeholders expect something from the public sector organisation - but the public sector organisation also wants something in return. Performance measurement should consider whether such stakeholders are delivering what the public sector organisation wants from them.

\section{THE PRISM}

The Performance Prism manages the performance through five interrelated angles.

1. Stakeholder's satisfaction - Map the stakeholders and their wants?

2. Stakeholder's contribution - Map the contribution from our stakeholders?

3. Strategies - what strategies do we need to put in place to satisfy the wants and needs of our stakeholders while satisfying our own requirements too? 
IBT JOURNAL OF BUSINESS STUDIES (IBT-JBS) Volume 16 Issue 1, 2020

4. Processes - what processes do we need to put in place to enable us to execute our strategies?

5. Capabilities - what capabilities do we need to put in place to allow us to operate our processes?

(The Performance Prism: The Scorecard for Measuring and Managing Business Success Pearson Education 2002, ISBN: 0273653342, 377 pages Andy Neely, Chris Adams, Mike Kennerley. Professor ANDY NEELY is Director of Research at Cranfield School of Management and Deputy Director of AIM, the Advanced Institute for Management Research. He is Chairman, Centre for Business Performance at Cranfield. CHRIS ADAMS and MIKE KENNERLEY are experienced researchers and consultants in this area)

When light falls onto a prism, it is refracted, showing the complexity of light. In a similar fashion Performance Prism shows the hidden complexities of a performance management program.

\section{STAKEHOLDER'S SATISFACTION \& CONTRIBUTION}

Neely and Adam recognize the importance of stakeholder mapping just like John Kotter, a master mind behind the change management philosophy. We will look at this angle from the first to fourth wheel perspective discussed earlier. i.e. which simply means all wheels will have to be seen through the performance prism. This will highlight the complexities of the performance management program in the public sector some of which have already been discussed earlier. Now each of the stake holder has different needs. For example, while the citizens of Pakistan demand the education and health services from the government but do they vote on the basis of these services or they give more importance to their ethnicity, bradri or tribe.

Also, we the citizens as a group are willing to pay taxes or most of us will evade taxes as in the past. While it is the responsibility of the bureaucracy to provide services to the citizens of Pakistan but the citizens have also something to contribute. Result will be a compromise on part of both parties and the journey will be slow.

Like wise the political leaders demand performance from the bureaucrats but do they celebrate and reward performance or their own agendas, like corrupt practices, nepotism and parchi system. Here also bureaucracy is required to give political leaders the performance that they desire but in return the bureaucracy also has a right to demand contribution from political leaders through their commitment to the well being of the civil service officers, and rewards for those who do well in terms of their performance. Judiciary another stake holder has to amend the laws to give room to performance-based consequence not the rewards and promotions based on service and seniority.

\section{STRATEGIES \& PROCESSES}

In Public sector strategy is critically important since each goal of every department is long term and it requires a proper strategy. For example, the goal of economic Page | 147 
growth or a seat on the security council, getting out of FATF grey list, a robust health care system, an effective education system all require a proper strategy to achieve that specific goal. Strategy in the Performance Prism means how the goal will be achieved.

After the goal has been set with all the stake holders i.e. who is going to deliver what, suitable strategies have to be defined with specific milestone to be achieved along the way

to determine whether they have the right business processes to support the strategies.

Performance measures will have to be developed to see how well these processes are working. Business process reengineering is a method used to identify redundant processes and Porter's Value chain analysis model is a way to identify the key processes. Identifying the key processes is one part but the capability of the people and availability of the technology and infrastructure required to operate the key processes is also equally essential. With out the capability of the people, technology and infrastructure even the best of the best process will fail to deliver the best outlined strategy.

Despite some individual successes, however, change remains difficult to pull off. Most of their initiatives have had low success rates. The brutal fact is that about $70 \%$ of all change initiatives fail. (Cracking Code of Change. Michael Beer Professor of Business Administration at Harvard Business School in Boston. He can be reached at mbeer@hbs.edu. Nitin Nohria, Professor of Business Administration at Harvard Business School. He can be reached at nnohria@hbs.edu. They are the authors of Breaking the Code of Change (Harvard Business School Press, 2000)

The same fact is reverberated across the globe by renowned researchers and professor. Most notably Professor Kotter who writes in his book and re-iterates in his other books and articles that change is hard. $70 \%$ change efforts fail (John P. Kotter 1996).

He also explains in his book; how can we pull off a major transformation such as implementing a robust and effective performance management program across the Public sector domain of Pakistan. His 8-step model is most effective in pulling off this kind of transition. Interesting to note is the fact that he also claims this model like wheels which have to be put in motion simultaneously and each step has to be given equal attention otherwise the change effort is bound to fail. In fact, a not perfect performance management system can work but a hasty deployment will surely fail. It is therefore recommended that the following 8 steps of successful transformation must be adopted if and when a performance management system is to be deployed for the public sector in Pakistan.

\section{EIGHT STEPS TO TRANSFORMATION}

1. Establishing a Sense of Urgency

2. Forming a Powerful Guiding Coalition

3. Creating a Vision 
IBT JOURNAL OF BUSINESS STUDIES (IBT-JBS) Volume 16 Issue 1, 2020

4. Communicating the Vision

5. Empowering Others to Act on the Vision

6. Planning for and Creating Short-Term Wins

7. Consolidating Improvements and Producing Still More Change

8. Institutionalizing New Approaches

(Source: Leading Change, 21 - The Heart of Change, 3-7. Leading Change, By John P. Kotter, Harvard Business School Press, 1996, Product no.7471, The heart of change: by Kotter, John P., and Dan S. Cohen Boston, Mass.: Harvard Business School Press, 2002. John P. Kotter is the Konosuke Matsushita Professor of Leadership (retired) at Harvard Business School in Boston.)

\section{6) CONCLUSION}

Pakistan has come a long way as a developing country and current reforms which are being undertaken are very promising but without the proper implementation of an effective performance management solution the transition from a fragile and vulnerable economy to a stable and strong economy will continue to remain a far cry. The tax payers' money will continue to be laundered and wasted. We also need to be cognizant of the fact that current governance structure of Pakistan is too top heavy to sustain. If the private sectors grow our exports and our manufacturing units reduce our dependencies on the imports, even then this heavy structure with hundreds of federal and provincial departments will be top heavy and will continue to threaten our existence and force us to pile up the debt burden. Therefore, we can safely conclude that a strong performance management program specifically tailored to the needs of our bureaucracy is the need of the hour for our beloved country. It is strongly recommended that a new performance management program is to be developed keeping in view the challenges of a political regime like Pakistan and consequences which can be applied consistently across the board. The implementation part must be done according to the principles of change management as propagated by Professor Kotter. "Long Live Pakistan".

\section{REFERENCES:}

A Guide to Performance Evaluation, Section 2 sub section ii clause (a) PAKISTAN PUBLIC ADMINISTRATION RESEARCH CENTRE MANAGEMENT SERVICES WING ESTABLISHMENT DIVISION ISLAMABAD (Edition 2004)

A Guide to Performance Evaluation, Section 2 sub section ii clause (a) PAKISTAN PUBLIC ADMINISTRATION RESEARCH CENTRE MANAGEMENT SERVICES WING ESTABLISHMENT DIVISION ISLAMABAD (Edition 2004).

Hanif, A., Jabeen, N. \& Jadoon, I., Z. (2016). Performance Management in Public Sector: A Case of Civil Service in Pakistan, South Asian Studies A Research Journal of South Asian Studies 31 (1). 
IBT JOURNAL OF BUSINESS STUDIES (IBT-JBS) Volume 16 Issue 1, 2020

Danielle S. Wiese, M. \& Ronald B. (1998), The evolution of the performance appraisal process. Journal of Management History 5(2).

Daley, M. D., (1991). Performance Appraisal in North Carolina Municipalities. Review of Public Personnel Administration. DOI: $10.1177 / 0734371 \times 9101100303$

Taylor F., W, (1911), The Principles of Scientific Management Page 141

Kotter, J. P., (1996). Leading Change, Harvard Business School Press.

Fitzgerald, L. (2001). PERFORMANCE MEASUREMENT IN SUCCESSFUL COMPANIES: THREE CASE STUDIES, Warwick Business School, University of Warwick Corpus ID: 14454334

Beer, M. \& Nohria, N. (2000). Cracking Code of Change. Harvard Business School Press.

Haque, N., \& Khawaja, I. (2007). Public service: Through the eyes of civil servants. Pakistan Institute of Development Economics Quaid-e-Azam University Campus PIDE Series on Governance and Institutions.. 30(4).

Robert S. Kaplan, S., R. \& Norton, P., D. (1992). The Balanced ScorecardMeasures that Drive Performance, Harvard Business Review 17(5).

Waters, T. \& Waters, D. (2015) Edited and Translated. Chapter 6 "Bureaucracy" from Max Weber's Rationalism and Modern Society: New Translations on Politics, Bureaucracy, and Social Stratification. 5(2).

Wilson, W. (1887). “The Study of Administration”, Political Science Quarterly 4(2). 